\title{
THE ROLE OF 3D MODEL AS SURGICAL GUIDANCE IN MANDIBULAR RECONSTRUCTION SURGERY
}

\author{
M. Adhitya Latief*, Benny S. Latief*, Lilies D.S.* \\ *Department Oral and Maxillofacial Surgery, Faculty of Dentistry, Universitas Indonesia, Jakarta \\ Correspondending: adhityalatief@yahoo.com
}

\begin{abstract}
reconstruction surgery is a challenging surgery that require well prepared presurgical plan to minimize the risk of failure, to accommodate the need for precision preoperative planning, surgeons frequently need guidance such as a 3-dimensional (3D) model to display complex cranial structures. Evaluation of the 3D model as surgical guidance require a review measurement regarding its efficiency and pitfalls. Purpose: the purpose of this research is to understand the importants key points that will resulted succesfull reconstructive surgery using 3D model as surgical guidance. Method: the evaluation of surgical result in mandibular reconstruction surgery from our Department Oral and Maxillofacial surgery, Universitas Indonesia from 2012 to 2017 reveal the differences. We analyze several keypoints that may affect to the succesfull of reconstruction surgery result. Result: we compared the result between years before and after 2015, this is where we start obligate all reconstruction surgery need to have preoperative planning using $3 D$ Model. Several keypoints in using 3D model is acknowledgeable. Conclusion: the use of $3 D$ models as surgical guidance has important role to minimize post reconstructive surgery result, surgeon need to understand the principal and keypoints in preoperative planning and regarding the use of $3 D$ model.
\end{abstract}

Keywords: 3D model, reconstruction plate, plate exposure, broken plate

\begin{abstract}
ABSTRAK
Latar belakang: bedah rekonstruksi adalah tindakan operasi yang penuh tantangan, tindakan ini memerlukan persiapan pre operasi seksama untuk meminimalisasi resiko kegagalan. Untuk mengakomodir kebutuhan tindakan persiapan pre operasi yang presisi maka dokter bedah memerlukan penggunaan model 3 Dimensi untuk menampilkan struktur kranial yang kompleks. Penggunaan model 3 Dimensi sebagai panduan operasi perlu dievaluasi sebagai penilaian keberhasilannya beserta kekurangannya pula. Tujuan: penelitian ini bertujuan untuk mengetahui poin penting dalam menghasilkan bedah rekonstruksi yang baik menggunakan model 3D sebagai petunjuk proses pembedahan. Metode: berdasarkan evaluasi hasil operasi bedah rekonstruksi pada mandibula yang dilakukan pleh Departemen Bedah Mulut dan Maksilofasial sejak 2012 sampai 2017 menunjukkan perbedaan. Kami menganalisa beberapa hal penting terkait keberhasilan hasil bedah rekonstruksi. Hasil: kami menganalisa hasil operasi bedah rekonstruksi mandibula sebelum dan sesudah tahun 2015, pada tahun tersebut center kami mulai menggunakan model 3 Dimensi sebagai prosedur wajib dalam persiapan preoperasi. Beberapa kunci pentig yang menentukan keberhasilan bedah rekonstruksi dapat kami temukan. Kesimpulan: penggunaan model 3 Dimensi sebagai acuan bedah rekonstruksi dapat meminimalisir komplikasi pasca bedah rekonstruksi, namun ahli bedah perlu memahami kunci pokok dan faktor yang berperan penting dalam persiapan pre operasi serta kaitannya dengan penggunaan model 3 Dimensi.
\end{abstract}

Kata kunci: model 3 dimensi, plat rekonstruksi, paparan plat, plat patah

\section{BACKGROUND}

$\mathrm{R}$ econstruction surgery had been evolving for several decades and keeps on developing with the progress of technology in the field of medicine, involving methods and surgical approaches that can be done. ${ }^{1}$ the bony resection and reconstruction were planned preoperatively based on computed tomographic data of the head and neck and lower leg. Three custom-made templates designed in a computer-assisted design and manufacturing software package and materialized by a selective laser sintering process (DuraForm PA, 3D Worknet, Ede, Netherlands It is a part of reconstruction surgery in the oral and maxillofacial area that included postablative surgery 
for such as removal of tumour, complex fracture, wound shot in maxillofacial region, infections with destruction of bone and any others. ${ }^{2}$

Most odontogenic tumors are a complex and diverse group oflesions affecting the maxillomandibular skeleton. Classification of these lesions is based upon their embryonic tissue origin namely epithelial, mesenchymal, or mixed. Ameloblastomas account for $1 \%$ of all oral tumors and $10 \%$ of all tumors from odontogenic origin. Surgical treatment of ameloblastomas depends on the size and location of the tumor, but for large or recurrent tumors, resection of the involved bone is the treatment of choice. For small defects, local resection, curettage, and bone grafting may be performed. For so called "giant" or "extreme" ameloblastomas, a resection and microvascular free flap with bone is often required. ${ }^{3} 20$ were identified with advanced disease (giant ameloblastoma

The mandibular reconstruction procedure is sometimes considered as part of a resection of the mandible for a tumour or neoplasm. The mandible is very important for facial esthetics and it is also responsible for mastication. The management of a mandible defect caused by tumor, trauma, or infection is a great challenge for surgeons because of the complexity of mandible anatomy and function. ${ }^{4}$ Optimal preparation of the mandibular reconstruction therefore needs a careful preoperative planning that could support the resection and reconstruction of mandible as well. ${ }^{4,5}$ The goal in all of these patients is to not only resect the tumor but to provide an orthognathically ideal reconstruction. ${ }^{3} 20$ were identified with advanced disease (giant ameloblastoma

Without proper preoperative planning, surgery result may have risk of failure such as plate or bone expose, reconstruction plate fracture, screw loosening etc. Preoperative planning need to be carefully planned to minimize the risk of failure, To accommodate the need for precision preoperative planning, surgeons frequently need guidance such as a 3-dimensional (3D) model to display complex cranial structures. ${ }^{6,7}$ available to craniomaxillofacial surgeons, allied to the rapid progress of technological developments, the use and production of 3D models has become important, especially for planning complex cases. The radiation exposure of additional $\mathrm{CT}$ based examinations is always subject to debate, so the feasibility of producing 3D models for surgical planning based on MRI imaging has been raised. Material and methods: 12 male and 3 female patients $(n=15$ Over the last decade, 3D models have been employed widely in maxillofacial surgery. ${ }^{8} \mathrm{a} 3 \mathrm{D}$ physical model of the medical image can be fabricated by RP manufacturing, and its virtual reality model can also be presented for visualization. CT images of a human skull and femur bone were used as the case studies for the construction of the 3D solid model with medical images. The STL models generated using this new methodology were compared to commercial computer-aided design (CAD This has tended to concentrate on the reproduction of exact physical replicas of patients' skeletal anatomy, which surgeons and prosthetic experts use to help plan reconstructive surgery and prosthetic rehabilitation. ${ }^{9}$

Before the 3D model era, using only radiographic imaging modality such as Plain X-ray photo/CT Scan/MRI or CBCT for region of the mandible and surrounding tissue is essential to decide the cutting margin, free tumour margin, choice of the plate, measurement of the plate, positioning and shape of the plate, deciding the length of the screws and simulating the end result. ${ }^{10}$ But then the rise of technology in field of radiology enabled imaging that could support the reconstructive mandible surgery. ${ }^{11}$ Nowadays the popular use of CBCT has been widely used for dentistry especially oral and maxillofacial surgeon, a conebeam CT scan is capable of helping reproduce measurements close to those obtained from actual samples; moreover, the image reproduction accuracy from a conebeam CT scan was greater than that from a helical CT. Furthermore, the "highprecision recon- structed $3 \mathrm{D}$ model" enables reliable visualization of full-sized oral and maxillofacial regions on both helical and conebeam $\mathrm{CT}$ scans. ${ }^{12}$

Using computer imaging software will able to process CT Scan or CBCT Data to be 3-Dimension imaging and convert it to be another data format, these kind of format then ready to be printed into 3D model as surgical guidance. ${ }^{13}$ it is of critical importance to have a precise model of the structures in question. Improved imaging techniques and advances in software engineering have moved three-dimensional (3D The advance technic in fabrication of 3D object has rise the ability to create an accurate geometrical structure of a replication object that very similar with the original object itself. ${ }^{14}$

Since its inception in 1986, additive manufacturing has used a digital model to manufacture a 3D solid object. The process, also known as rapid prototyping, expanded widely in the 1990s in architecture and manufacturing. The terms additive manufacturing and rapid prototyping are, for the purpose of this review, synonymous with $3 \mathrm{D}$ printing. ${ }^{15}$ Another term that is regularly used is stereolithography, it is actually a different technique that is used in fabrication of a 3D model. It is the first method introduced in 1986 to built a 3D model. This technology has rapid developing in upcoming years, but however, our center is familiar with this term since it was introduced in early years. ${ }^{16}$ Rapid prototyping (RP) or also known as 3D modelling comes as a new technology for the purpose of assisting the surgeon in the visual and tactile aspects of surgery, providing diagnostic accuracy and increasing the success of surgical planning, and thus, improving outcomes and reducing complications, risks, operative time and the overall cost of treatment. 


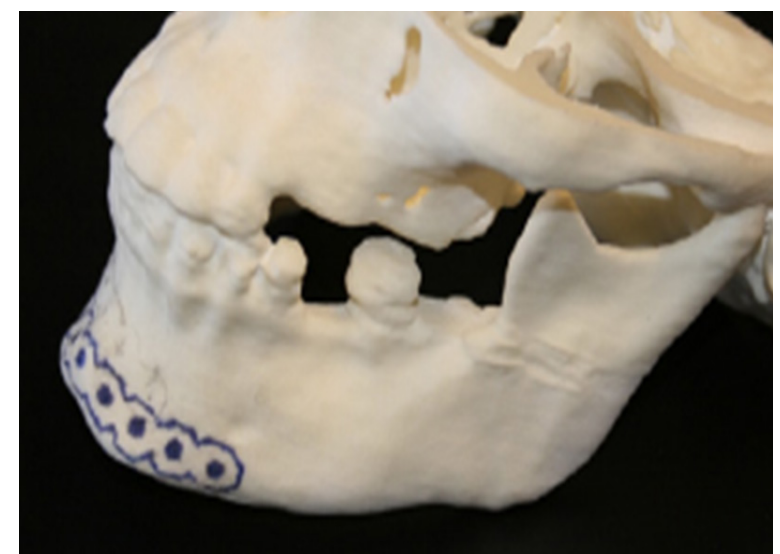

Figure 1. 3D Model made with FDM printer as surgical mock up

It is a constructive, additive process used to obtain physical prototypes from a digital threedimensional model. Based on this three-dimensional model, 3D modelling systems build prototypes by successively adding fine layers of specific materials. ${ }^{17}$

The use of 3D model as surgical guidance has been proven helpfull in our department, since 2015 we regularly use 3D model as surgical planning. However, several keypoints in using 3D model as surgical guidance need to have more attention.

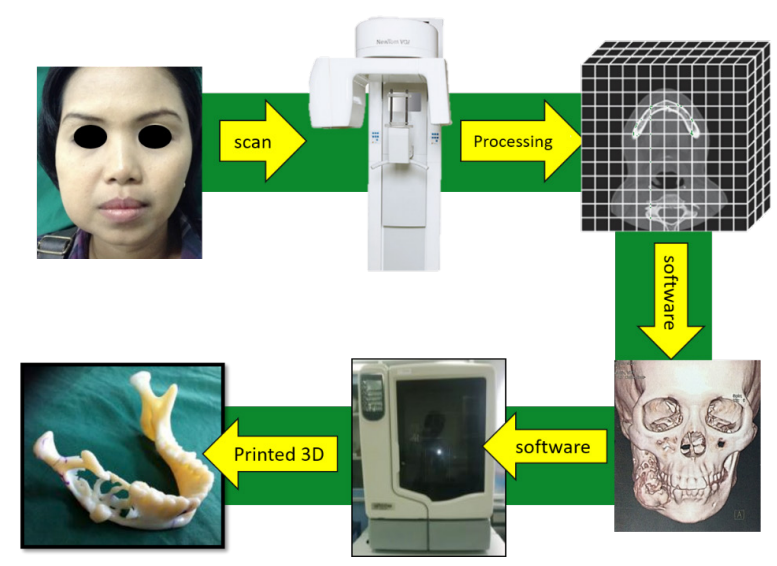

Figure 2. flow processing patient to create 3D Printing model. Patient need to have scan either from CBCT or CT Scan, the imaging data will be processed using computer software and printed using $3 \mathrm{D}$ printer.

Since the usage of 3D model as surgical guidance became more popular in our daily preoperative procedure, we need an evaluation regarding its effectiveness and efficiency as surgical guidance, this evaluation review will measure our surgical result especially for any complications that might occur post operatively. Any complications might resulted from poor understanding of preoperative planning and the usage of 3D model for surgical guidance. We analyze the complications that occur and found some keypoints that has important role for the succesfull use of 3D model as surgical guidance.

The purpose of this research is to understand the importants key points that will resulted succesfull reconstructive surgery using 3D model as surgical guidance. The role of 3D model is an important factor as part of presurgical planning, but without understanding the proper use of $3 \mathrm{D}$ model will result complications that might occur post operatively.

\section{METHOD}

In this Descriptive research, we evaluate 113 patient that undergone surgery for mandibular reconstruction using reconstruction plate in Dept OMFS Univ. Indonesia - Cipto Mangunkusumo Hospital, Jakarta, Indonesia from November 2012 to May 2017. All patient had previous surgery for resection of mandible with various bone lesion diagnosis such as ameloblastoma, Odontogenic Kerato Cyst (OKC), Ossifying Fibroma etc. That require resection such as en bloc resection, segmental resection, partial resection to total mandibular resection. Post resection, patient had reconstruction surgery using mandibular reconstruction and follow up from 36 month up to 5 years post surgery. Patients were evaluated for any complication and failure with clinical examination and diagnostic imaging. Definition of successful reconstruction surgery was defined as a reconstruction plate in place with or without osseous reconstruction, or osseous reconstruction without reconstruction plate. A plateassociated complication was defined as the need for any reoperation as a result of loosening of osteosynthesis screws, malposition, intraoral or extraoral exposure of the plate, or infection without exposure. ${ }^{18}$

Before surgery, all patient had biopsy and sent to histopathological anatomy department, however post surgery patient will also had post surgical speciment to be sent again as confirmation of diagnose. All patient had radiological examination in oral and maxillofacial using MS CT Scan or CBCT depend on patient condition and size of lesion. For presurgical planning is usully been done one week before surgery.

\section{RESULT}

We evaluate all 113 reconstruction case that we followed up. Before the usage of 3D Model as preoperative planning, result reveal failure such as plate expose, reconstruction plate fracture and infection. Failure rate did decreased sigfnificantly after the usage of 3D model, however failure such as infection and plate fracture are still occur. We analyze all failure and manage to identified some key points when surgical planning was done using reconstruction plate and $3 \mathrm{D}$ model that may increase risk of failure without proper management. In total there are 56 male patients sample and 57 female patients sample that 
recorded from 2012-2017 had mandible reconstructive surgery, this shows that diversity of sample has equal amount regarding gender as shown in table 1. Based on diagnosis, ameloblastoma cases is the highest prevalence for mandible reconstruction surgery, in total there are 99 cases of ameloblastoma parient samples during 2012-2017 from total of 113 patients, this also confims the previous study about the prevalence case of mandible tumour by Vitria et.al in 2011 that shown high prevalence of ameloblastoma case during 2002-2008 in Cipto Mangunkusumo Hospital. ${ }^{19}$ Other condition that require mandible reconstruction surgery such as Odontogenic Keratocyst (OKC), Ossifying fibroma and other benign bone lesion are equally distribute with much smaller amount of cases during year 2012-2017 as shown in table 2.

Table 1. Patient with Reconstruction Surgery based on Gender (2012-2017)

\begin{tabular}{lccc}
\hline \multirow{2}{*}{ Gender } & \multicolumn{2}{c}{$\begin{array}{c}\text { Mandible Reconstruction } \\
\text { Surgery }\end{array}$} & \\
\cline { 2 - 3 } & $\begin{array}{c}\mathbf{2 0 1 2 - 2 0 1 4} \\
\text { (without 3D } \\
\text { model) }\end{array}$ & $\begin{array}{c}\mathbf{2 0 1 5 - 2 0 1 7} \\
\text { (With 3D } \\
\text { Model) }\end{array}$ & \\
\hline Men & 36 & 20 & 56 \\
\hline Women & 31 & 26 & 57 \\
\hline Total & 67 & 46 & 113 \\
\hline
\end{tabular}

Table 2. Patient with Reconstruction Surgery based on Diagnosis (2012-2017)

\begin{tabular}{lccc}
\hline \multicolumn{4}{c}{ Mandible Reconstruction } \\
Dugnosis & $\begin{array}{c}\text { 2012 - 2014 } \\
\text { (without 3D } \\
\text { model) }\end{array}$ & $\begin{array}{c}\text { 2015-2017 } \\
\text { (With 3D } \\
\text { Model) }\end{array}$ & Total \\
\cline { 2 - 3 } & 60 & 39 & 99 \\
\hline Ameloblastoma & 2 & 4 & 6 \\
\hline OKC & 2 & 2 & 4 \\
\hline $\begin{array}{l}\text { Ossifying } \\
\text { fibroma }\end{array}$ & 3 & 1 & 4 \\
\hline $\begin{array}{l}\text { Other benign } \\
\text { bone lesion }\end{array}$ & 67 & 46 & 113 \\
\hline Total & & & 4 \\
\hline
\end{tabular}

From table 3, Several failure or complication that we found are such as exposure of reconstruction plate, broken/plate fracture and infection. All failure are identified based on clinical and radiological examination, these complications are found after several years, some therapies such as debridement and antibiotics therapy could control the complications in infected patients, but in severe infection case or involving the damage of reconsytruction plate need further therapy such as plate replacement or 2nd surgery for bone graft and reconstruction plate placenent. The most complication occurs is plate expose, this might occur during healing period where wound dehiscence will lead to plate exposure, in latter stage might developt as infection and the worst will resulted to broken plate but this also might occur from poor bending of reconstruction plate and trauma.

Table 3. Patient with Complication Post Reconstruction Surgery (2012-2017)

\begin{tabular}{lccc}
\hline \multirow{2}{*}{$\begin{array}{c}\text { Failure and } \\
\text { Complications }\end{array}$} & $\begin{array}{c}\text { Mandible Reconstruction } \\
\text { Surgery }\end{array}$ & $\begin{array}{c}\text { 2012-2014 } \\
\text { (without 3D } \\
\text { model) }\end{array}$ & $\begin{array}{c}\mathbf{2 0 1 5 - 2 0 1 7} \\
\text { (With 3D } \\
\text { Model) }\end{array}$ \\
\hline Plate Expose & 7 & 1 & 8 \\
\hline $\begin{array}{l}\text { Broken/Plate } \\
\text { fracture }\end{array}$ & 3 & 1 & 4 \\
\hline Infection & 3 & 3 & 6 \\
\hline Total & 13 & 5 & 18 \\
\hline
\end{tabular}

Most of patient with complication come with complain of discomfort and pain that occur after 6 month post surgery, this might happened necause most of patient stop having appointment for control post surgery at that time. The complication might seen intra oral as in case of plate exposure or infection, and some cases can be found on extra oral examination where deformity of facial asymetri is obviously seen. In several cases patient didnt notice that there was complication, patient felt discomfort of clicking sound when opening mouth but from panoramic examination reveal sign of plate fracture.

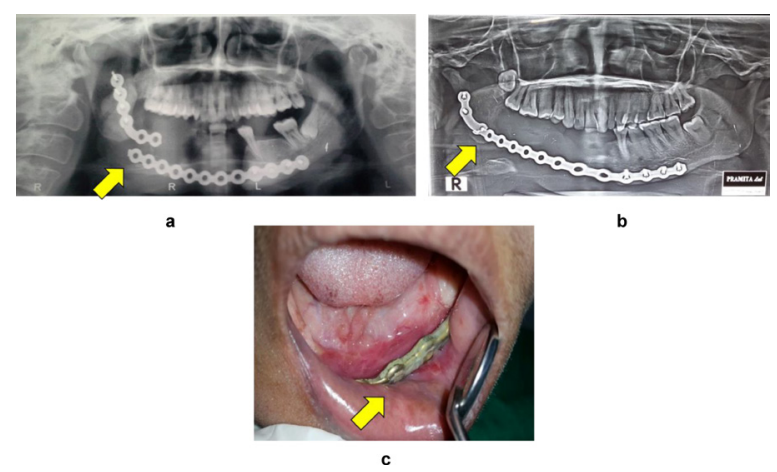

Figure 3. a. Fractured reconstruction plate with obvious displacement with clinical deformity. $b$. Fractured plate without any displacement, patient only complain about clicking sound when opening mouth. c. Plate exposure because of poor oral hygiene, this condition may occur after chronic infection in intra oral. 
Treatment for this complication is usually taken care as soon as possibly, for acute infection that might occur less than 6 month usually can be resolved bt medication and conservative therapy, but re-surgical need to be performed in severe or chronic cases. Failure of the plate was defined as no reconstruction plate in place and no osseous reconstruction anywhere within the follow-up period. ${ }^{18}$

Using 3D model as surgical guidance has many advantages in mandibular reconstruction, The primary advantages reported are 1) shorter surgical time, 2) improved adaptation of reconstruction plates, 3) reduced fatigue of the metal, and 4) improved impact on the patient of the disease diagnosis, easier patient education, and a clear method for surgical planning. However, despite many advantages, there are also some reported disadvantages such as 1) the requirement of a high-resolution $\mathrm{CT}$ scan, 2) cost, and 3 ) additional steps in surgical planning. ${ }^{20}$

\section{DISCUSSION}

Based on our findings, several complication occurs related to plate condition and infection, even some infection case extends into intra oral soft tissue and affect the plate to be exposed. The complication might appear as acute problem that occur less than 1 month post surgery such as infection case, although this might be reduced with oral medication, late infection might still occurs and developt worsening. Other condition such as plate fracture is identified after patient complain sudden deviation or malocclusion, this condition confirmed by using panoramic photo.

Resolution of complication case that appear are done by surgical revision, from our findings, especially regarding reconstruction plate, we identified the problems that occurs is because of poor planning and positioning of plate. Significant result .appears when we started using 3D Model planning since 2015 for reconstruction surgery, since then we manage to decrease more than $60 \%$ complication case on following years. However complication still occurs but mostly not related with plate problems. Several important factors that we manage to identified which has important role in preventing complication of reconstructive surgery in mandible is as followings.

Keypoints on 3D model as surgical guidance:

1. Use 3D model to measure tumour margin, estimate plate lenght and screws to use

To guide the surgery more precisely, surgeons are trying to simulate mandible reconstruction and to fabricate the reconstructed model and template for surgery preop- eratively this also confirms the research afrom Zheng et al (2012) about the role 3D planning to simulate mandible reconstruction. ${ }^{4}$ Having to simulate original condition will lead better understanding for plate placement and bending, the placement of minimum 3 screw in each side is based on AOCMF principles about the biomechanical properties of reconstruction plate in ability to resorb any forces given to mandible. This properties need to have attention since the reconstruction plate only combined bicortical screws with the precise diameter to hold the plate in place. Any improper size and amount of screw will result loosening and displacement of plate in the mandibular bone.

2. Use 3D model contour as guidance for prebending plate with under contour position

To have best adaptation with considering the mandibular arch and shape, a proper prebending need to consider original natural contour of mandible. An undercountour bending is preferable for reconstruction surgery since the risk of muscle and suture tension is a risk that might occur post surgical. Having undercontour will ensure there is no tension when surgeon suture the intra and extra oral region. Over contour plate will resulted tension and un-natural dimension of mandible. Patient should not planned to have normal contour like in non lesion part of jaw, this is due there will be lack of tissue than been taken during resection, so undercontour plate is preferable.

By accommodating the reconstruction plate to the model preoperatively and then using it as a surgical template during surgery, the facial contour of the patient is more acceptable, this also corresponding the reasearch from Cohen et al (2009) with the same result. ${ }^{21}$ Which assists in accurate contouring of plates and/or planning of bone graft harvest geometry before surgery. The 2 most commonly used rapid prototyping technologies are stereolithography and 3D printing (3DP

3. Bend reconstruction plate with sequence

The metal used as reconstruction plate is titanium, it is considered the best option for reconstruction plate since it has low risk of allergic reaction, light enough in weight yet has strong mechanical properties. But the disadvantage, it has durability that could decrease because of fatigue stress, this might increase if surgeon decide to prebend the plate over and over multiple times, that is why a prebending plate should be performed according to 3 step sequence which is: $a$. in plane bending, $b$. out of plane bending, c. Torqueing bending.

4. Make sure suture in surround of reconstruction plate is water tight suture and no tension.

Important examination on clinical view is intra oral in post surgical patient, this evaluation will decide prospective result in the future outcomes. One of evaluation is the suture in intra oral, mostly the early days of surgery we could see if the suturing had any loosening or exposure, if this is condition 
not be revised, furthermore could result infection, exposure and in the end will be failure that need resurgery. To prevent risk of infection, a water tight suture should be performed layer by layer after the placement and fixation of reconstruction plate, a water tight suture will prevent saliva and food debris to containate the wound that might contact with inner layer of wound closure. Most of these problems could be seen in 2-3 weeks after surgery, usually this is triggered since patient will start to eat soft diet intra orally.

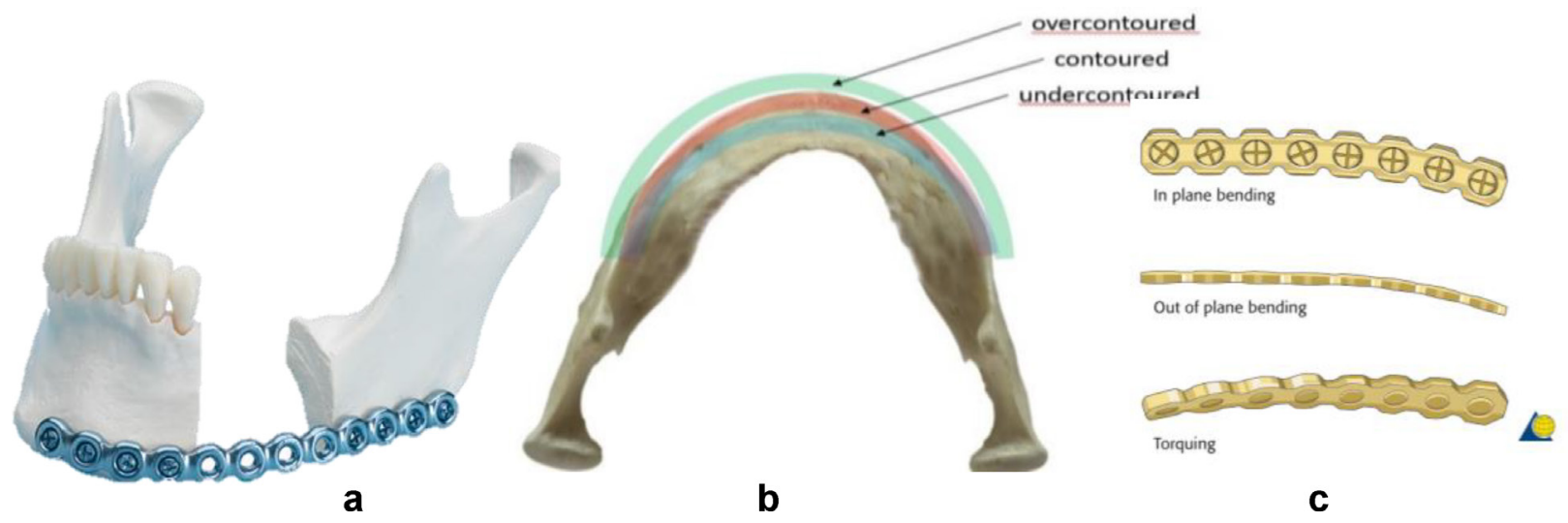

Figure 4. a. Reconstruction plate is bended based on 3D model to decide proper length and shape including the amount and positioning of screws. B. Guidance for prebending plate on 3D model need to adjust based on undercontour position. C. Sequence in prebending plate need to follows the following steps: inplane, out of plane and torqueing bending.

\section{CONCLUSION AND SUGGESTION}

The use of 3D model could help and minimize the risk of failure by using it as surgical guidance in preoperative planning, this is inline with the result from Wang et al (2009) and Rana (2013) about the importance of 3D model as surgical guidance., The mandible has a unique configuration that varies among individuals in curvature, length, and height which differ from other maxillofacial bone. Not just for restoring function, the aim of reconstruction surgery is to recover the original configuration of the mandible so as to optimize the facial contour and the occlusal relationship. Currently, the application of 3D model in mandible reconstruction has simplified this complicated procedure as surgical guidance. ${ }^{4}$

The usage of $3 \mathrm{D}$ model as part of preoperative surgical planning enables surgical simulation of the resective and reconstructive phases together with the obtention of three-dimensional models, prebent reconstruction plates and surgical guides and templates in order to improve precision and efficiency during resection. This conclude the result by Rohner et al (2013) that define the importance of $3 \mathrm{D}$ model as preoperative surgical planning. ${ }^{22}$ massive recurrence required radical resection of the left orbit and reconstruction with cranial bone grafts and a free latissimus dorsi flap. Postoperative radiotherapy resulted in local osteoradionecrosis. Surgical revision and restoration of the maxillary defect with a prefabricated fibula flap was performed. The authors provide ample information on the application of computer-aided design and manufacturing (CADCAM In the future, with the advance of technology, this methods will have improvement which will ease operator to perform surgery, lower risk of complication and the most important is better result.

\section{REFERENCES}

1. Coppen C, Weijs W, Bergé SJ, Maal TJJ. Oromandibular reconstruction using 3D planned triple template method. J Oral Maxillofac Surg. 2013;71(8):243-247. doi:10.1016/j.joms.2013.03.004

2. van Gemert JTM, van Es RJJ, Van Cann EM, Koole R. Nonvascularized Bone Grafts for Segmental Reconstruction of the Mandible-A Reappraisal. J Oral Maxillofac Surg. 2009;67(7):1446-1452. doi:10.1016/j. joms.2008.12.052

3. Broer PN, Tanna N, Franco PB, et al. Ten-year evolution utilizing computer-assisted reconstruction for giant ameloblastoma. $J$ Reconstr Microsurg. 2013;29(212):173-180. doi:10.1055/s-0032-1331144

4. Zheng G Sen, Su YX, Liao GQ, et al. Mandible reconstruction assisted by preoperative virtual surgical simulation. Oral Surg Oral Med Oral Pathol Oral Radiol. 2012;113(5):604-611. doi:10.1016/j.tripleo.2011.05.016

5. Kermer C, Lindner a., Friede I, Wagner a., Millesi W. Preoperative stereolithographic model planning for primary reconstruction in craniomaxillofacial trauma surgery. J Cranio-Maxillo-Facial Surg. 1998;26:136139. doi:10.1016/S1010-5182(98)80002-4

6. Reinbacher KE, Wallner J, Kärcher H, Pau M, 
Quehenberger F, Feichtinger M. Three dimensional comparative measurement of polyurethane milled skull models based on $\mathrm{CT}$ and MRI data sets. $J$ Cranio-Maxillofacial Surg. 2012;40(8):e419-e425. doi:10.1016/j.jcms.2012.02.019

7. Huotilainen E, Jaanimets R, Valášek J, et al. Inaccuracies in additive manufactured medical skull models caused by the DICOM to STL conversion process. J CranioMaxillofacial Surg. 2014;42:259-265. doi:10.1016/j. jcms.2013.10.001

8. Wang CS, Wang WH a, Lin MC. STL rapid prototyping bio-CAD model for CT medical image segmentation. Comput Ind. 2010;61(3):187-197. doi:10.1016/j. compind.2009.09.005

9. Essig H, Rana M, Kokemueller H, et al. Pre-operative planning for mandibular reconstruction - A full digital planning workflow resulting in a patient specific reconstruction. Head Neck Oncol. 2011;3(1):45. doi:10.1186/1758-3284-3-45

10. Apajalahti S, Kelppe J, Kontio R, Hagström J. Imaging characteristics of ameloblastomas and diagnostic value of computed tomography and magnetic resonance imaging in a series of 26 patients. Oral Surgery, Oral Med Oral Pathol Oral Radiol. 2015;120(2):e118-e130. doi:10.1016/j.oooo.2015.05.002

11. Sa A, Kauke M, Timmer M, et al. Does volumetric measurement serve as an imaging biomarker for tumor aggressiveness of ameloblastomas ? 2018;78(November 2017):16-24. doi:10.1016/j.oraloncology.2018.01.002

12. Katsumura S, Sato K, Ikawa T, Yamamura K, Ando E, Shigeta Y. " High-precision, reconstructed 3D model " of skull scanned by conebeam CT : Reproducibility verified using CAD / CAM data. 2016;18:37-43. doi:10.1016/j.legalmed.2015.11.007

13. Varga E, Hammer B, Hardy BM, Kamer L. The accuracy of three-dimensional model generation. What makes it accurate to be used for surgical planning? Int J Oral Maxillofac Surg. 2013;42(9):1159-1166. doi:10.1016/j. ijom.2013.02.006
14. Güngör E, Doğan MS. Reliability and accuracy of conebeam computed tomography voxel density and linear distance measurement at different voxel sizes: A study on sheep head cadaver. J Dent Sci. 2017;12(2):145-150. doi:10.1016/j.jds.2016.11.004

15. Giannopoulos AA, Cai T, George E, et al. Medical 3D Printing for the Radiologist. RadioGraphics. 2015;35(7):1965-1988.

16. Jacobs PF. Stereolithography and Other RP\&M Technologies: From Rapid Prototyping to Rapid Tooling. Society of Manufacturing Engineers; 1996. https:// books.google.co.id/books?id=3YI0gvTyGtEC.

17. Farias TP, Dias FL, Sousa BA, Galvão MS, Bispo D, Pastl AC. Prototyping: Major Advance in Surgical Planning and Customizing Prostheses in Patients with Bone Tumors of the Head and Neck. 2013;2013(July):17.

18. Rijt EEM Van Der, Noorlag R, Koole R, Abbink JH, Rosenberg AJWP. Predictive factors for premature loss of Martin 2.7 mandibular reconstruction plates. Br J Oral Maxillofac Surg. 2015;53(2):121-125. doi:10.1016/j. bjoms.2014.10.010

19. Sandini SU, Vitria EE, Santoso TI. Profile of Ameloblastoma from a Retrospective Study in Jakarta , Indonesia. 2011;18(2):27-32.

20. Azuma M, Yanagawa T, Kanno NI, et al. Mandibular reconstruction using plates prebent to fit rapid prototyping 3-dimensional printing models ameliorates contour deformity. 2014:1-8.

21. Cohen A, Laviv A, Berman P, Nashef R, Abu-Tair J. Mandibular reconstruction using stereolithographic 3-dimensional printing modeling technology. Oral Surgery, Oral Med Oral Pathol Oral Radiol Endodontology. 2009;108(5):661-666. doi:10.1016/j. tripleo.2009.05.023

22. Rohner D, Guijarro-Martínez R, Bucher P, Hammer B. Importance of patient-specific intraoperative guides in complex maxillofacial reconstruction. J CranioMaxillofacial Surg. 2013;41(5):382-390. doi:10.1016/j. jems.2012.10.021 